\title{
Dietary vitamin E inhibits the trans 10-18:1 shift in beef backfat
}

\author{
Manuel Juárez ${ }^{1}$, Michael E. R. Dugan ${ }^{1,4}$, Jennifer L. Aalhus ${ }^{1}$, Noelia Aldai ${ }^{1}$, \\ John A. Basarab ${ }^{2}$, Vern S. Baron ${ }^{1}$, and Tim A. McAllister ${ }^{3}$ \\ ${ }^{1}$ Agriculture and Agri-Food Canada, Lacombe Research Centre, 6000 C \& E Trail, Lacombe, Alberta, Canada T4L \\ 1W1; ${ }^{2}$ Western Forage/Beef Group, Alberta Agriculture and Rural Development, Research Centre, 6000 C \& E \\ Trail, Lacombe, Alberta, Canada T4L 1W1; and ${ }^{3}$ Agriculture and Agri-Food Canada, Research Centre, 5403-1st \\ Ave. S., Lethbridge, Alberta, Canada T1J 4B1. Contribution no. 1149. Received 25 September 2009, \\ accepted 3 December 2009.
}

\begin{abstract}
Juárez, M., Dugan, M. E. R., Aalhus, J. L., Aldai, N., Basarab, J. A., Baron, V. S. and McAllister, T. A. 2010. Dietary vitamin E inhibits the trans 10-18:1 shift in beef backfat. Can. J. Anim. Sci. 90: 9-12. Forty feedlot steers were fed a barley-

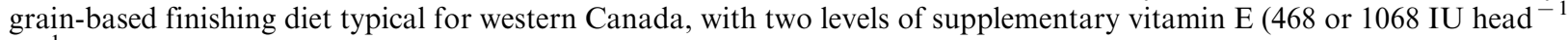
$\mathrm{d}^{-1}$ ) and the effect on backfat trans-18:1 isomeric profile was determined. Feeding 1068 IU vitamin E reduced the total trans-18:1 content in backfat $(P<0.01)$, as well as the percentage of trans 10-18:1 $(P<0.001)$, which are related to an increased risk for cardiovascular diseases. On the other hand, trans 11-18:1 (vaccenic acid) the precursor for cis 9,trans 1118:2 (rumenic acid), which have several purported health benefits, increased $(P<0.01)$. Vitamin E could, therefore, be used to decrease trans-18:1 in beef and improve its isomeric profile.
\end{abstract}

Key words: Beef, trans fatty acid, vaccenic acid, vitamin E

\begin{abstract}
Juárez, M., Dugan, M. E. R., Aalhus, J. L., Aldai, N., Basarab, J. A., Baron, V. S. et McAllister, T. A. 2010. Le vitamine E des aliments entrave la conversion des acides gras trans 10-18:1 dans le gras dorsal des bovins. Can. J. Anim. Sci. 90: 9-12. Quarante bouvillons d'engrais ont reçu une ration de finition à base d'orge typique à celle employée dans l'ouest du Canada, mais enrichie de vitamine $\mathrm{E}$ à deux concentrations (468 ou 1068 UI par tête, quotidiennement), avant établissement du profil isomérique des acides gras trans-18:1 pour le gras dorsal. La dose de 1068 UI de vitamine E diminue la concentration totale d'acides gras trans-18:1 dans le gras dorsal $(P<0,01)$, ainsi que la proportion des acides gras trans 10-18:1 $(P<0,001)$ associés à un risque plus élevé de maladies cardiovasculaires. Parallèlement, on note une hausse $(P<0,01)$ de la concentration de l'acide gras trans 11-18:1 (acide vaccénique), précurseur de l'acide gras cis 9,trans 11-18:2 (acine ruménique), qu'on présume avoir plusieurs effets bénéfiques sur la santé. Par conséquent, on pourrait se servir de la vitamine E pour réduire la concentration d'acides gras trans-18:1 dans le bœuf et rehausser le profil isomérique de cette viande.
\end{abstract}

Mots clés: Bœuf, acides gras trans, acide vaccénique, vitamin E

Vitamin E, due to its effects on nutritional myopathy, retinal degeneration, erythrocyte hemolysis and prostaglandin biosynthesis, is an essential nutrient for the growth and health of beef cattle (Machlin 1985; McDowell et al. 1996). Furthermore, vitamin $\mathrm{E}$ is widely used as an antioxidant in biological systems, and its accumulation in muscle has been shown to have a positive impact on colour and lipid stability of fresh and frozen beef (Liu et al. 1995). Recent results also suggest that dietary vitamin E can prevent the "trans 11 to trans 10-18:1 shift" in milk and plasma of dairy cattle

${ }^{4}$ To whom correspondence should be addressed (e-mail: Mike.Dugan@agr.gc.ca).
(Kay et al. 2005; Pottier et al. 2006). High levels of barley, typically used in finisher diets in western Canada, produce a rumen environment conducive to biohydrogenation of polyunsaturated fatty acids (PUFA) through the trans 10-18:1 pathway resulting in an increased rate of its deposition (Dugan et al. 2008). In fact, trans 10-18:1 has been shown to be the major trans 18:1 isomer in Canadian retail beef (Aldai et al. 2009). Cardiovascular health risks in humans and animal models (Hodgson et al. 1996; Bauchart et al. 2007; Roy et al. 2007) have been associated with trans 10-18:1. Therefore, development of strategies to decrease trans 10-18:1 levels in beef would be positive for

Abbreviations: PUFA, polyunsaturated fatty acids 
both consumers and producers. On the other hand, trans 11-18:1 (vaccenic acid) could have beneficial effects on human health by itself (Tholstrup et al. 2006) and by its conversion to cis 9,trans 11-18:2 (CLA, rumenic acid), which has been shown to provide protection against cancer, diabetes and inflammatory diseases in both animal and cell models (Belury 2002; Ip et al. 2003). The present study was undertaken to elucidate the effect of dietary vitamin $\mathrm{E}$ on the detailed trans-18:1 profile of backfat from beef cattle fed a typical western Canadian finisher diet high in ground barley.

\section{Animal Management}

Animals were raised and slaughtered in accordance with the principals and guidelines established by the Canadian Council on Animal Care (1993). Forty feedlot steers were housed in four feedlot pens (two pens per dietary treatment, 10 animals per pen, $n=20$ animals per dietary treatment) and fed ad libitum diets consisting of $72.8 \%$ steam-rolled barley, $22 \%$ alfalfa/brome hay, $2.73 \%$ feedlot $(32 \%$ CP) supplement, $1.73 \%$ vitamin/mineral premix, $0.39 \%$ molasses, $0.39 \%$ canola oil and contained $22 \mathrm{mg} \mathrm{kg}^{-1}$ monensin (as-fed basis; $86.4 \%$ dry matter). The combined feedlot supplement and vitamin/mineral premix contained ( $\%$ basis) $\mathrm{Ca}$, 8.63, P, 2.10, Na, 1.25, K, 0.65, Mg, 0.20, S, 0.24 (on a $\mathrm{mg} \mathrm{kg}^{-1}$ basis) Mn, 2186, Zn, 2788, Fe, 948, Cu, 903, Co, 17, I, 48, Se, 14 (on an IU basis) vitamin A, 240 200, vitamin $D, 44$ 930, vitamin $E, 910$. The finishing diet was fed over a 90-d period and animals were not treated with any growth implants. Dietary treatments consisted of Control (39 IU dl- $\alpha$-tocopheryl acetate per kilogram of basal diet (as fed) providing 468 IU per animal per day) and vitamin $\mathrm{E}$ (468 IU vitamin $\mathrm{E}$ from the basal diet with $600 \mathrm{IU} \mathrm{dl}-\alpha$-tocopheryl acetate of vitamin $\mathrm{E}$ top dressed per animal feed allocation per day providing a total 1068 IU per animal per day).

\section{Carcass Measurements and Sampling}

Animals were slaughtered over five slaughter dates (four animals per dietary treatment per slaughter day) at a target ultrasound backfat measurement of $8-9 \mathrm{~mm}$. At $24 \mathrm{~h}$, the left loin was dissected from the carcass and a sample of backfat was collected and stored at $-80^{\circ} \mathrm{C}$ for further fatty acid analysis.

\section{Fatty Acid Analysis}

Backfat samples $(50 \mathrm{mg}$ ) were freeze-dried and directly methylated with sodium methoxide. The trans-18:1 isomers were analyzed using two complementary GLC temperature programs (Dugan et al. 2007; Kramer et al. 2008) and their contents were expressed as percentage of total trans-18:1 isomers.

\section{Statistical Analysis}

Statistical analysis of fatty acids were performed using the PROC MIXED procedure of SAS software (SAS
Institute, Inc. 2003), and, initially, vitamin E treatment was included as the main effect, pen as a random effect and slaughter date as a blocking factor. A pen effect was not found for any fatty acid studied and, therefore, it was removed from the statistical model, leaving individual animal as experimental unit according to procedures described by Gill et al. (2008). The LSMEANS and PDIFF options were used for generating least squares means and comparison of treatments by F-test.

\section{Results and Discussion}

Feeding 1068 IU vitamin E to cattle on a high-barley finisher diet reduced total trans-18:1 in backfat by $27 \%$ compared with the control diet $(3.85 \pm 0.439$ vs. $2.81 \pm$ 0.430 , respectively; $P<0.01$ ). As previously observed by other authors in high-concentrate-fed beef cattle, trans 10-18:1 was the major trans-18:1 isomer, followed by trans 11-18:1 (Dugan et al. 2007; Aldai et al. 2008). The increase in dietary vitamin $\mathrm{E}$ resulted in increases $(P<0.05)$ in trans 4, 5, 11, 13/14 and 16-18:1 and decreases $(P<0.01)$ in trans $6 / 7 / 8$ and 10-18:1 (Figs. 1 and 2). Among trans isomers, the reduction of trans 1018:1 $(-46 \%)$ and the increase of trans 11-18:1 (+28\%) in the high vitamin $\mathrm{E}$ group were of the greatest magnitude. The prevention of the "trans 11- to trans 10-18:1 shift" was previously observed in plasma (Kay et al. 2005) and milk (Pottier et al. 2006) when feeding supplementary vitamin $\mathrm{E}$, even when high levels of PUFA were included in the diet. These results indicate that vitamin $\mathrm{E}$ can influence ruminal pathways of PUFA biohydrogenation although the mechanism has not been firmly established. Differences in the rumen environment, primarily affected by diet, can influence rumen microbial population (Klieve et al. 2003). Furthermore, Pottier et al. (2006) hypothesized that vitamin $\mathrm{E}$ could also act either as an inhibitor of bacteria producing trans 10-18:1 or as an electron acceptor for Butyrivibrio fibrisolvens, a species mainly

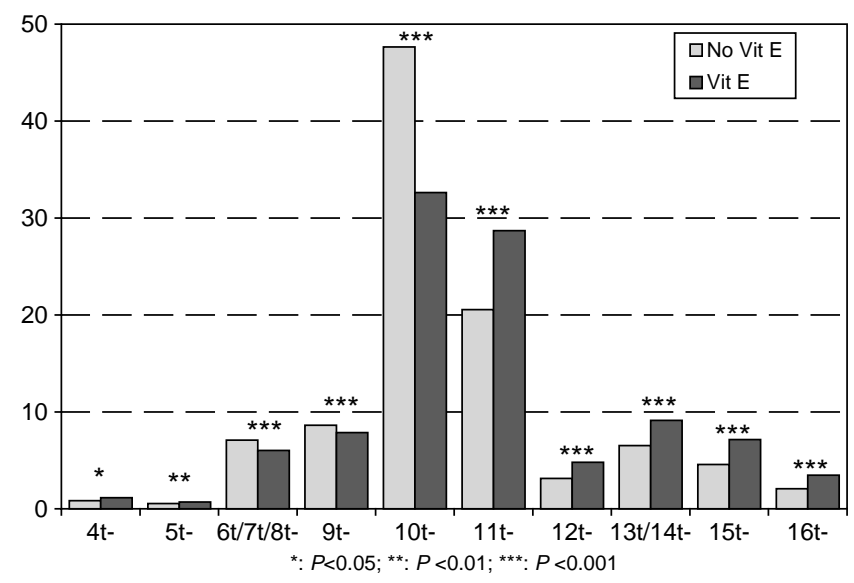

Fig. 1. Effect of high dietary vitamin E on trans-18:1 isomeric profile ( $\%$ of total trans 18:1 fatty acids) of backfat from steers fed a high barley finisher diet. 


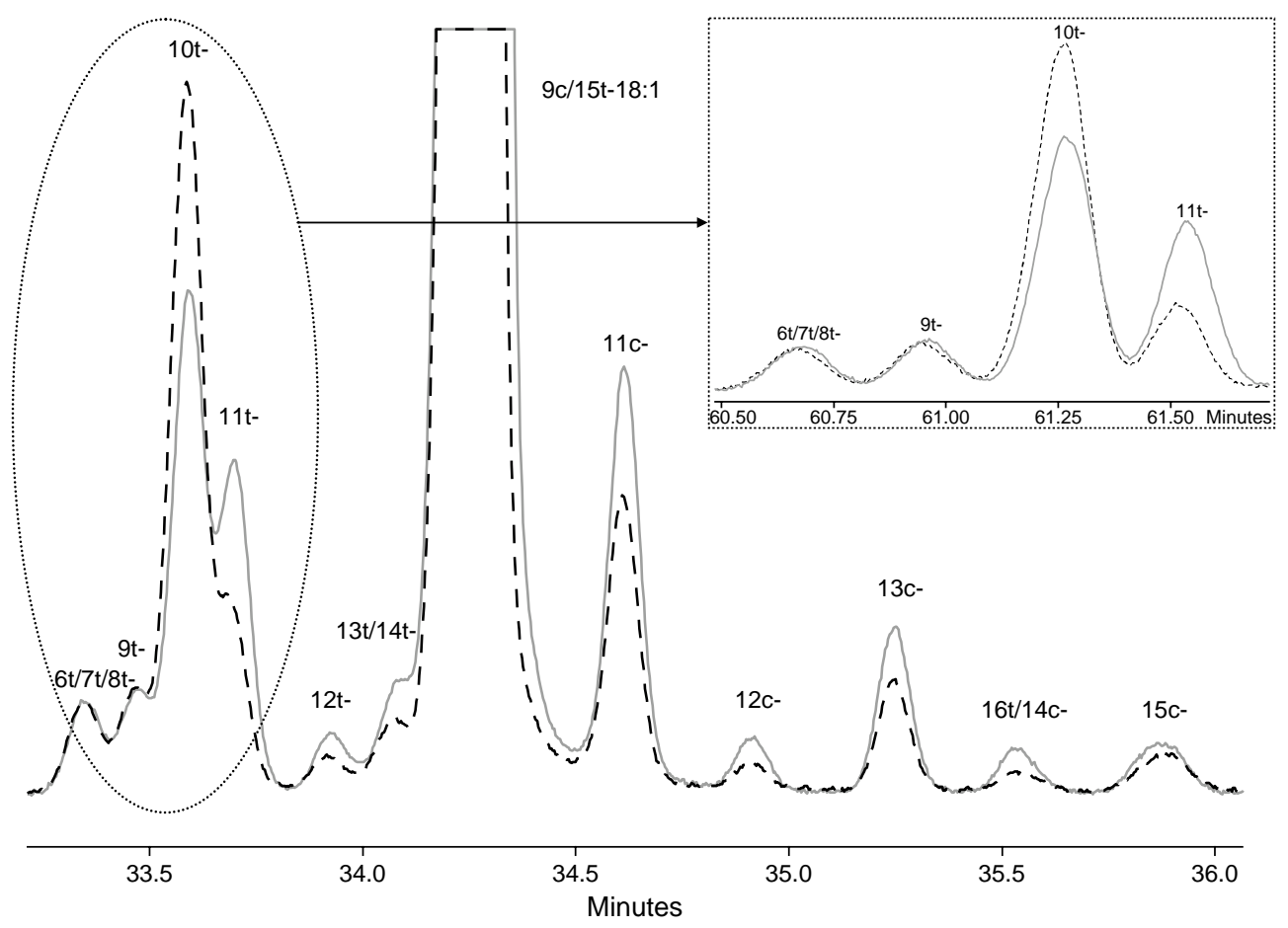

Fig. 2. Representative trans-18:1 region partial GLC chromatograms of backfat using $175^{\circ} \mathrm{C}$ (main) and $150^{\circ} \mathrm{C}$ (zoom) temperature programs (Control: dotted line; High vitamin E: solid line).

related to fibre digestion (i.e., pasture-based feeding). This may be due to $\alpha$-tocopherol's structural similarity to other compounds (e.g., $\alpha$-tocopherolquinol and deoxy- $\alpha$-tocopherolquinol) involved in the biohydrogenation of cis 9,trans 11-18:2 to trans 11-18:1 (Hughes and Tove 1980a,b). On the other hand, environmental stress has been shown to be an important factor for bacterial production of trans fatty acids (Härtig et al. 2005). Therefore, an alternative hypothesis could be that vitamin $\mathrm{E}$ alleviates oxidative stress on bacteria resultant from changes in ruminal conditions resulting in lower production rates of trans fatty acids.

In conclusion, based on previous studies on plasma and milk and present findings in meat, vitamin E may be useful as a simple and effective way to decrease trans18:1 in beef and improve its isomeric profile when feeding high-concentrate diets. Its effective level and interaction with diets high in PUFA, therefore, warrant further investigation as a means to increase tissue levels of beneficial biohydrogenation products (i.e., trans 1118:1 and cis 9,trans 11-18:2), which have many known health benefits.

Dr. M. Juárez acknowledges the receipt of a NSERC fellowship funded through the AAFC ABIP-FOBI program. Dr. N. Aldai gratefully acknowledges the receipt of a research contract from the 7th European Community Program (Marie Curie International Outgoing Fellowship).
Aldai, N., Dugan, M. E. R., Kramer, J. K. G., Mir, P. S. and McAllister, T. A. 2008. Nonionophore antibiotics do not affect the trans-18:1 and conjugated linoleic acid composition in beef adipose tissue. J. Anim. Sci. 86: 3522-3532.

Aldai, N., Dugan, M. E. R., Rolland, D. C. and Kramer, J. K. G. 2009. Survey of the fatty acid composition of Canadian beef: Backfat and longissimus lumborum muscle. Canadian J. Anim. Sci. 89: 315-329.

Bauchart, D., Roy, A., Lorenz, S., Chardigny, J. M., Ferlay, A., Gruffat, D., Sébédio, J. L., Chilliard, Y. and Durand, D. 2007. Butters varying in trans 18:1 and cis-9,trans-11 conjugated linoleic acid modify plasma lipoproteins in the hypercholesterolemic rabbit. Lipids 42: 123-133.

Belury, M. A. 2002. Dietary conjugated linoleic acid in health: Physiological effects and mechanisms of action. Annu. Rev. Nutr. 22: 505-531.

Canadian Council on Animal Care. 1993. A guide to the care and use of experimental animals. E. B. Olfert, B. M. Cross, and A. A. McWilliam, eds. Vol. 1. 2nd ed. CCAC, Ottawa, ON.

Dugan, M. E. R., Kramer, J. K. G., Robertson, W. M., Meadus, W. J., Aldai, N. and Rolland, D. C. 2007. Comparing subcutaneous adipose tissue in beef and muskox with emphasis on trans 18:1 and conjugated linoleic acids. Lipids 42: 509-518. Dugan, M. E. R., Rolland, D. C., Aalhus, J. L., Aldai, N. and Kramer, J. K. G. 2008. Subcutaneous fat composition of youthful and mature Canadian beef: Emphasis on individual conjugated linoleic acid and trans-18:1 isomers. Can. J. Anim. Sci. 88: 591-599.

Gill, R. K., Vanoverbeke, D. L., Depenbusch, B., Drouillard J. S. and Dicostanzo, A. 2008. Impact of beef cattle diets 
containing corn or sorghum distillers grains on beef color, fatty acid profiles, and sensory attributes. J. Anim. Sci. 86: 923-935.

Härtig, C., Loffhagen, N. and Harms, H. 2005. Formation of trans fatty acids is not involved in growth-linked membrane adaptation of Pseudomonas putida. Appl. Environ. Microbiol. 71: 1915-1922.

Hodgson, J. M., Wahlqvist, M. L., Boxall, J. A. and Balazs N. D. 1996. Platelet trans fatty acids in relation to angiographically assessed coronary artery disease. Atherosclerosis 120: 147-154.

Hughes, P. E. and Tove, S. B. 1980a. Identification of an endogenous electron donor for biohydrogenation as $\alpha$-tocopherolquinol. J. Biol. Chem. 255: 4447-4452.

Hughes, P. E. and Tove, S. B. 1980b. Identification of deoxy- $\alpha-$ tocopherolquinol as another endogenous electron donor for biohydrogenation. J. Biol. Chem. 255: 11802-11806.

Ip, M. M., Masso-Welch, P. A. and Ip, C. 2003. Prevention of mammary cancer with conjugated linoleic acid: Role of the stroma and the epithelium. J. Mamm Gland Biol. Neoplas. 8: 103-118.

Kay, J. K., Roche, J. R., Kolver, E. S., Thomson, N. A. and Baumgard, L. H. 2005. A comparison between feeding systems (pasture and TMR) and the effect of vitamin E supplementation on plasma and milk fatty acid profiles in dairy cows. J. Dairy Res. 72: 322-332.

Klieve, A. V., Hennessy, D., Ouwerkerk, D., Forster, R. J., Mackie, R. I. and Attwood, G. T. 2003. Establishing populations of Megasphaera elsdenii YE 34 and Butyrivibrio fibrisolvens YE 44 in the rumen of cattle fed high grain diets. J. Appl. Microbiol. 95: 621-630.

Kramer, J. K. G., Hernandez, M., Cruz-Hernandez, C., Kraft, J. and Dugan, M. E. R. 2008. Combining results of two GC separations partly achieves determination of all cis and trans 16:1, 18:1, 18:2 and 18:3 except CLA isomers of milk fat as demonstrated using Ag-ion spe fractionation. Lipids 43: 259-273.

Liu, Q., Lanari, M. C. and Schaefer, D. M. 1995. A review of dietary vitamin E supplementation for improvement of beef quality. J. Anim. Sci. 73: 3131-3140.

Machlin, L. J. 1985. Advances in vitamin E research. Vitamins 59: 253-261.

McDowell, L. R., Williams, S. N., Hidiroglou, N., Njeru, C. A., Hill, G. M., Ochoa, L. and Wilkinson, N. S. 1996. Vitamin E supplementation for the ruminant. Anim. Feed Sci. Technol. 60: 273-296.

Pottier, J., Focant, M., Debier, C., De Buysser, G., Goffe, C., Mignolet, E., Froidmont, E. and Larondelle, Y. 2006. Effect of dietary vitamin $\mathrm{E}$ on rumen biohydrogenation pathways and milk fat depression in dairy cows fed high-fat diets. J. Dairy Sci. 89: 685-692.

Roy, A., Chardigny, J. M., Bauchart, D., Ferlay, D., Lorenz, S., Durand, D., Gruffat, D., Faulconnier, Y., Sébédio, J. L. and Chilliard, Y. 2007. Butters rich either in trans-10-c18:1 or in trans-11-c18:1 plus cis-9, trans-11 CLA differentially affect plasma lipids and aortic fatty streak in experimental atherosclerosis in rabbits. Animal 1: 467-476.

SAS Institute, Inc. 2003. SAS ${ }^{\circledR}$ user's guide: Statistics. SAS for windows. Version 9.1. SAS Institute, Inc., Cary, NC.

Tholstrup, T., Raff, M., Basu, S., Nonboe, P., Sejrsen, K. and Straarup, E. M. 2006. Effects of butter high in ruminant trans and monounsaturated fatty acids on lipoproteins, incorporation of fatty acids into lipid classes, plasma c-reactive protein, oxidative stress, hemostatic variables, and insulin in healthy young men. Am. J. Clin. Nutr. 83: 237-243. 